\title{
Synaptic vesicle cycling is not impaired in a glutamatergic and a cholinergic synapse that exhibit deficits in acidification and filling
}

\author{
Bento João Abreu*, Luciana Ferreira Leite, Débora Lopes Oliveira, Ernani Amaral
}

\author{
Department of Morphology, Biological Sciences Institute, Federal University of Minas Gerais, Belo Horizonte
}

\begin{abstract}
The purpose of the present work was to investigate synaptic vesicle trafficking when vesicles exhibit alterations in filling and acidification in two different synapses: a cholinergic frog neuromuscular junction and a glutamatergic ribbon-type nerve terminal in the retina. These synapses display remarkable structural and functional differences, and the mechanisms regulating synaptic vesicle cycling might also differ between them. The lipophilic styryl dye FM1-43 was used to monitor vesicle trafficking. Both preparations were exposed to pharmacological agents that collapse $\Delta \mathrm{pH}\left(\mathrm{NH}_{4} \mathrm{Cl}\right.$ and methylamine $)$ or the whole $\Delta \mu \mathrm{H}+$ (bafilomycin), a necessary situation to provide the driving force for neurotransmitter accumulation into synaptic vesicles. The results showed that FM1-43 loading and unloading in neuromuscular junctions did not differ statistically between control and experimental conditions ( $\mathrm{P}>0.05)$. Also, FM1-43 labeling in bipolar cell terminals proved highly similar under all conditions tested. Despite remarkable differences in both experimental models, the present findings show that acidification and filling are not required for normal vesicle trafficking in either synapse.
\end{abstract}

Uniterms: Synaptic vesicle. Acidification. Lipophilic styryl dye/use. Neuromuscular junction. Bipolar cell. Retina.

\begin{abstract}
O objetivo do presente trabalho foi investigar o tráfego de vesículas sinápticas quando estas apresentam alterações no armazenamento de neurotransmissores e acidificação em duas distintas sinapses: a junção neuromuscular colinérgica de rãs versus o terminal nervoso glutamatérgico do tipo ribbon em céulas bipolares da retina. Essas sinapses exibem notáveis diferenças estruturais e funcionais e os mecanismos de regulação de ciclo das vesículas sinápticas podem ser diferentes entre eles. Para monitorar o tráfego de vesícula, foi utilizado o marcador lipofílico FM1-43. Ambas as preparações foram expostas a agentes farmacológicos que provocam o colapso de $\Delta \mathrm{pH}\left(\mathrm{NH}_{4} \mathrm{Cl}\right.$ e metilamina) ou de todo $\Delta \mu \mathrm{H}+$ (bafilomicina), gradientes necessários para o acúmulo de neurotransmissores em vesículas sinápticas. Nossos resultados demonstram que a marcação e desmarcação de FM1-43 nas junções neuromusculares não foi estatisticamente diferente entre as diversas condições experimentais $(\mathrm{P}>0,05)$. Além disso, a marcação de FM1-43 em terminais sinápticos de células bipolares foram bastante semelhantes em todas as condições testadas. Apesar das diferenças marcantes em ambos os modelos experimentais, nossos achados demonstram que a acidificação e o preenchimento de vesículas sinápticas não são necessários para o tráfico normal da vesícula nas sinapses estudadas.
\end{abstract}

Uniterms: Vesículas sinápticas. Acidificação. Marcador lipofílico/uso. Junções neuromusculares Células bipolares. Retina.

\section{INTRODUCTION}

Neurotransmitters are packed in synaptic vesicles (SV) and released by the fusion of a vesicle with the

"Correspondence: B. J. Abreu. Departmento de Morfologia, Instituto de Ciências Biológicas, Universidade Federal do Rio Grande do Norte, BR 101- Lagoa Nova - 59072-970 - Natal - RN, Brazil. E-mail: abreubj@gmail.com presynaptic membrane, a synaptic step called exocytosis. During endocytosis, empty vesicles must be recycled, acidified and re-internalized with transmitters in a rapid fashion to sustain another SV cycle (Sudhof, 2004). The driving force for neurotransmitter accumulation in $\mathrm{SV}$ is provided by the generation of a transmembrane electrochemical gradient $(\Delta \mu \mathrm{H}+)$ that has a chemical gradient $(\Delta \mathrm{pH}$, inside acidic) and an electrical potential across 
the vesicular membrane ( $\Delta \Psi$, inside positive). $\Delta \mu \mathrm{H}+$ is generated in situ by the electrogenic vacuolar $\mathrm{H}+$-ATPase ( $\mathrm{VH}^{+}$-ATPase), which is responsible for acidification and rendering the vesicle lumen positive (Nelson, 1992).

The bioenergetics of vesicular amino acid transport differs dramatically from that of vesicular amine and acetylcholine transport (Liu, Edwards, 1997). While glutamate transport shows maximum activity under high $\Delta \Psi$ conditions and inhibition by increasing concentrations of chloride or permeant anions that maximize $\Delta \mathrm{pH}$ at the expense of $\Delta \Psi$ (Maycox et al., 1988), acetylcholine transport depends largely on $\Delta \mathrm{pH}$ (van der Kloot, 2003). Additionally, controversy remains over whether glutamate uptake is driven solely by $\Delta \Psi$ (Hartinger \& Jahn, 1993; Maycox et al., 1988) or by both $\Delta \Psi$ and $\Delta \mathrm{pH}$ of the $\Delta \mu \mathrm{H}+$ (Naito, Ueda, 1985; Tabb et al., 1992; Wolosker et al., 1996). It appears that $\Delta \Psi$ plays a primary role in glutamate uptake but $\Delta \mathrm{pH}$ may still be essential to antagonize glutamate efflux and retain glutamate inside the vesicles (Wolosker et al., 1996).

Some studies have attempted to investigate how vesicle trafficking occurs in SVs with alterations in neurotransmitter filling (Hong, 2001; Lima et al., 2010; Parsons et al., 1999; Van der Kloot et al., 2002; Zhou et al., 2000) and acidification (Cousin, Nicholls, 1997). They indicated that SV filling is not required for vesicle cycling although the physiological meaning of this data has yet to be elucidated. Unfortunately, the studies above used different experimental models (with distinct neurotransmitter internalization bioenergetics) and stimulus protocols, hampering comparison of results. Also, there is no data available on partially-filled or empty vesicles cycling in the non-conventional ribbon type synapse.

In the present work, using lipophilic styryl dye FM1-43 to monitor exo-endocytosis and pharmacological agents that collapse gradients of $\Delta \mu \mathrm{H}+$, we investigated whether filling and acidification are required for the SV cycle in the cholinergic frog neuromuscular junction and the glutamatergic ribbon type nerve terminal in the retina.

\section{EXPERIMENTAL PROCEDURES}

\section{Material}

FM1 $-43^{\circledR}$ was purchased from Invitrogen ${ }^{\mathrm{TM}}$. Methylamine and bafilomycin were purchased from SigmaAldrich. All other chemicals and reagents were of analytical grade. All procedures were approved by the local animal care committee (CETEA-UFMG) and followed the guidelines for the Use and Care of Animals for Research issued by the NIH.

\section{Frog neuromuscular junction experiments and imaging analysis}

Frog cutaneous pectoris nerve muscle preparations were dissected from Rana catesbeiana $(\sim 60 \mathrm{~g})$ and mounted in a sylgard-lined chamber. FM1-43 (4 $\mu \mathrm{M})$ was used to stain the recycling pool of synaptic vesicles (Betz et al., 1992). This constitutes a styryl dye widely used to track exocytosis, endocytosis and recycling of secretory granules and vesicles (revised by Amaral et al., 2011). The dye presents a hydrophobic tail that reversibly binds to membranes, a positive head that prevents membrane permeation, and a body with aromatic rings and a double bond that determines spectral fluorescence properties. Also, FM1-43 is weakly fluorescent in water but its fluorescence intensity is higher in lipid environments. Thus, FM1-43 labels membranes without trespassing them. When the nerve terminal is submitted to a stimulus that evokes exocytosis, the compensatory endocytosis internalizes the dye and results in terminal staining. If the nerve terminal is submitted to a new round of stimulus, the exocytosis of the recycling pool would produce terminal destaining.

The muscles were incubated with $d$-tubocurarine $(16 \mu \mathrm{M})$ to prevent contractions during stimulation or image acquisition. Destaining in the absence of stimulus (photobleaching) was used as a control. Experimental neuromuscular preparations were incubated with $\mathrm{NH}_{4} \mathrm{Cl}(30 \mathrm{~mm})$, methylamine $(10 \mathrm{~mm})$ and bafilomycin $(1 \mu \mathrm{M})$ for 1 hour. After labeling with FM1-43, exocytosis was investigated by the exposure of neuromuscular preparations to a high $\mathrm{K}^{+}$solution $(60 \mathrm{~mm} \mathrm{KCl})$ alone or associated to $\mathrm{NH}_{4} \mathrm{Cl}$, methylamine or bafilomycin. Images were acquired at 5-min intervals until the end of the experiments using a fluorescence microscope (Zeiss Axioskop) coupled to a CCD camera (12 bits, Micromax) and visualized on a computer screen. The microscope was equipped with water immersion objectives (63X, 0.95 NA and 40X, 0.75 NA) and standard fluorescein optics (excitation $480 \mathrm{~nm}$, dichroic $505 \mathrm{~nm}$, emission $535 \mathrm{~nm}$ long pass). Excitation light was provided by a $100 \mathrm{~W} \mathrm{Hg}$ lamp. Image analysis was performed using software Image J, which allows the brightness levels emitted from regions of interest to be measured. Mean fluorescence intensity was determined for each group of spots and plotted as a percentage of its mean initial fluorescence using Microsoft Excel and Sigma Plot 10.0 software.

\section{Goldfish ribbon synapse experiments and imaging analysis}

Bipolar cells were acutely dissociated from the retina of goldfish (Carassius auratus auratus), according 
to von Gersdorff and Matthews (1994). Goldfish were dark-adapted for $1 \mathrm{~h}$ and killed by decapitation followed immediately by destruction of the brain and spinal cord. The eyeballs were removed and retinae dissected out and treated for $25 \mathrm{~min}$ with hyaluronidase to remove vitreous humor. Each retina was quartered, placed ganglion cell layer down on filter paper and kept at $4^{\circ} \mathrm{C}$ in medium comprising (mm): $\mathrm{NaCl} 127, \mathrm{KCl} 2.5, \mathrm{MgCl}_{2} 1.0, \mathrm{CaCl}_{2} 0.5$, Hepes 5 and glucose 12, adjusted to $\mathrm{pH} 7.45$ with $\mathrm{NaOH}$. Slices were cut into smaller pieces and mounted in a perfusion chamber. FM1-43 fluorescence was imaged with a Zeiss water immersion objective (40x, 1.2 NA) coupled to a Zeiss LSM 510 laser scanning confocal microscope located at CEMELUFMG. A 488 argon laser was used to excite the preparation using FITC optics. Dissociated bipolar cells were kept in Fish Ringer associated with methylamine (10 mM), $\mathrm{NH}_{4} \mathrm{Cl}$ (30 mm) or bafilomycin (500 nM) for 5 min before FM1-43 staining. Based on Lagnado and colleagues (1996), bipolar cell membranes were first stained with FM1-43 (4 $\mu \mathrm{M})$, $0 \mathrm{~mm} \mathrm{Ca}^{2+}$ and $\mathrm{KCl} 50 \mathrm{~mm}$ (iso-osmotic replacement with $\mathrm{NaCl}$ ) but in association with methylamine, $\mathrm{NH}_{4} \mathrm{Cl}$ or bafilomycin. After $120 \mathrm{~s}$, bipolar cells were perfused with fish Ringer containing FM1-43 (4 $\mu \mathrm{M}), \mathrm{Ca}^{2+}(2.5 \mathrm{mM})$ and $\mathrm{KCl}(50 \mathrm{~mm})$ for $360 \mathrm{~s}$ in the continued presence of each pharmacological agent, resulting in an image. Fluorescence measurements were performed using the Metamorph Imaging System 3.6 software (Universal Imaging Corporation). Briefly, cell terminal areas at the best focus were quantified as gray level index for FM1-43 fluorescence (control) and after drug exposure. Values were plotted on a graph (Sigma Plot 10.0).

\section{Statistical analysis}

Statistical analysis was performed using the paired students $t$-test or ANOVA. ${ }^{*} P$ values $<0.05$ were considered statistically significant.

\section{RESULTS AND DISCUSSION}

Figure 1A shows an ex-vivo preparation of frog neuromuscular junction stained with FM1-43 (4 $\mu \mathrm{M})$ during a high $\mathrm{K}^{+}$stimulus ( $\mathrm{KCl} 60 \mathrm{~mm}$ for $10 \mathrm{~min}$ ). Each fluorescent spot represents clusters of SVs labeled with the dye. $\mathrm{NH}_{4} \mathrm{Cl}$ and methylamine are membrane-permeable weak bases that decrease acidification by disrupting the $\Delta \mathrm{pH}$ (Abreu et al., 2008; Cousin, Nicholls, 1997; van der Kloot, 1987; Zoccarato et al., 2003). Since $\Delta \mathrm{pH}$ is required for vesicle loading with acetylcholine, its disruption by $\mathrm{NH}_{4} \mathrm{Cl}$ or methylamine decreases SV filling (Cousin, Nicholls, 1997; Van der Kloot, 1987). Even in the presence of $\mathrm{NH}_{4} \mathrm{Cl}$ or methylamine, motor terminals were labeled with FM1-43 during a high $\mathrm{K}^{+}$stimulus with a similar intensity to that observed under the control condition (Figure 1B, 1C and $1 \mathrm{E})$. Moreover, stimulation with high $\mathrm{K}^{+}$solution in the presence of bafilomycin, a potent $\mathrm{VH}^{+}$-ATPase inhibitor that completely blocks vesicle loading due to entire $\Delta \mu \mathrm{H}+$ collapse (Moriyama et al., 1990), produced FM1-43 labeling equivalent to the control condition (Figure 1D and 1E).

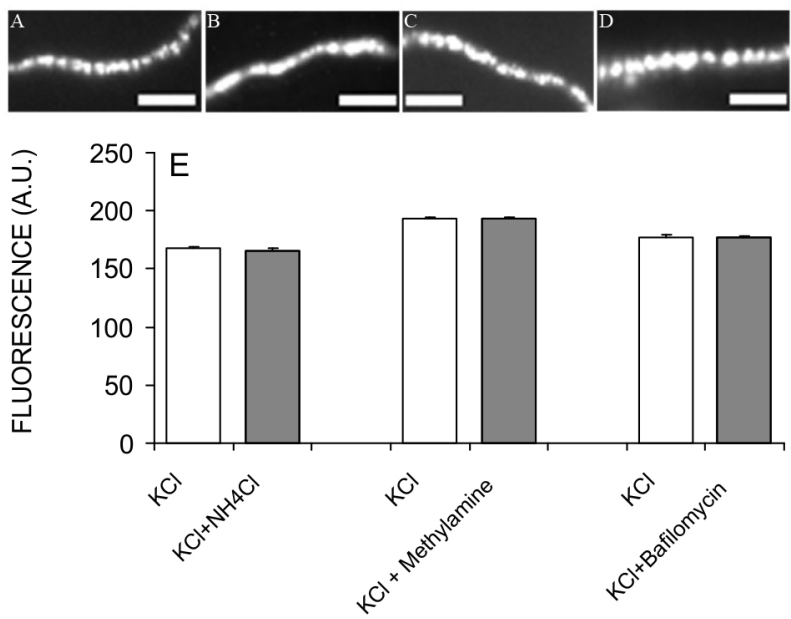

FIGURE 1 - Endocytosis is not affected by drugs that inhibit vesicle filling at the frog neuromuscular junction. Frog nerve terminal labeled with FM1-43 during stimulation with $\mathrm{KCl}$ $60 \mathrm{~mm}$ (A), $\mathrm{KCl} 60 \mathrm{~mm}+\mathrm{NH}_{4} \mathrm{Cl} 30 \mathrm{~mm}$ (B), $\mathrm{KCl} 60 \mathrm{~mm}+$ methylamine $10 \mathrm{M}(\mathbf{C})$ and $\mathrm{KCl} 60 \mathrm{~mm}+$ bafilomycin $1 \mu \mathrm{M}(\mathbf{D})$. Scale Bar for all images $=10 \mu \mathrm{m}$. Quantification of FM1-43 staining after $30 \mathrm{~min}$ of stimulation with $\mathrm{KCl}, \mathrm{KCl}+\mathrm{NH} 4 \mathrm{Cl}$, $\mathrm{KCl}+$ methylamine and $\mathrm{KCl}+$ bafilomycin, respectively $(\mathbf{E})$. Observe that agents which collapse the electrochemical gradient and lead to a decrease in quantal content did not interfere with endocytosis of synaptic vesicles and FM1-43 uptake. Error bars: \pm SEM of 1.110 spots from 237 nerve terminals.

To determine whether SVs with reduced quantal content can be released, FM1-43 destaining induced by high $\mathrm{K}^{+}$solution in the control condition was compared to destaining in the presence of $\mathrm{NH}_{4} \mathrm{Cl}$, methylamine or bafilomycin. Figure 2 (panels A, C, E, G and I) shows frog motor nerve terminals labeled with FM1-43. Figure 2 also depicts fluorescence loss due to photobleaching (panel 2B), FM1-43 destaining induced by high $\mathrm{K}^{+}$in the control condition (panel 2D) and the destaining caused by high $\mathrm{K}^{+}$in the presence of $\mathrm{NH}_{4} \mathrm{Cl}$, methylamine and bafilomycin (panels $2 \mathrm{~F}, 2 \mathrm{H}$ and $2 \mathrm{~J}$, respectively). As can be seen in Figure 2K, inhibition of vesicle filling with neurotransmitter had no influence on FM1-43 destaining.

Next, we tested whether SV cycling occurs normally at bipolar cell terminals in the retina. Synaptic terminals 

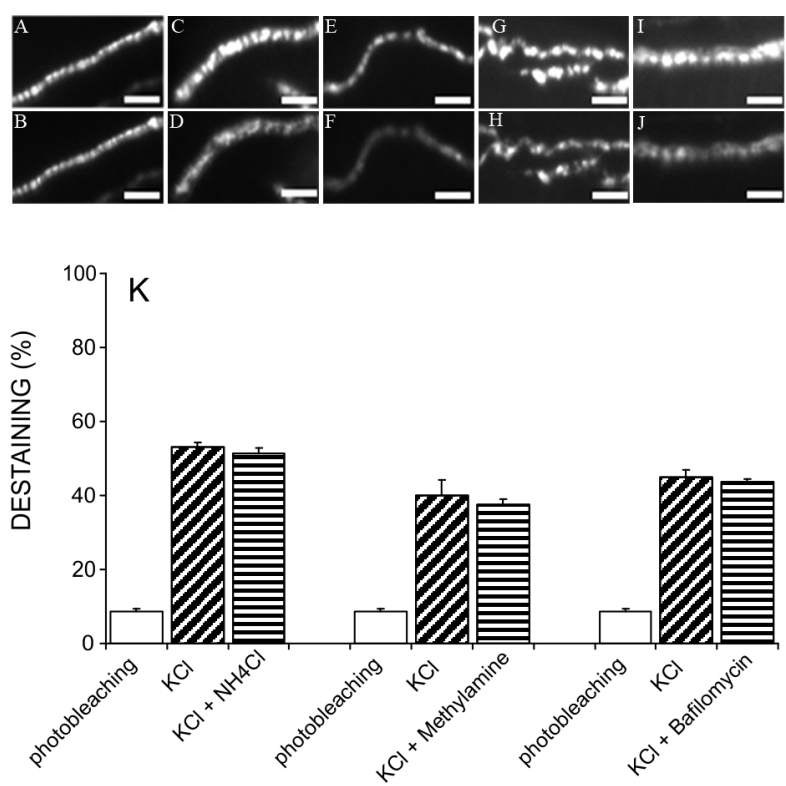

FIGURE 2 - Inhibition of synaptic vesicle filling did not influence exocytosis at the frog neuromuscular junction. Frog neuromuscular junctions labeled with FM1-43 during stimulation with $\mathrm{KCl} 60 \mathrm{~mm}$ (A and $\mathbf{C}$ ), $\mathrm{KCl}+\mathrm{NH}_{4} \mathrm{Cl} 30 \mathrm{~mm}(\mathbf{E}), \mathrm{KCl}+$ methylamine $10 \mathrm{~m}(\mathbf{G})$ and $\mathrm{KCl}+$ bafilomycin $1 \mu \mathrm{M}(\mathbf{I})$. FM1-43 destaining after $30 \mathrm{~min}$ of image acquisition due to photobleaching (B), stimulation with $\mathrm{KCl} 60 \mathrm{~mm}(\mathbf{D}), \mathrm{KCl}+\mathrm{NH}_{4} \mathrm{Cl} 30 \mathrm{~mm}(\mathbf{F})$, $\mathrm{KCl}+$ Methylamine $10 \mathrm{M}(\mathbf{H})$ or $\mathrm{KCl}+$ bafilomycin $1 \mu \mathrm{M}(\mathbf{J})$. Quantification of FM1-43 destaining due to photobleaching or stimulation with $\mathrm{KCl}, \mathrm{KCl}+\mathrm{NH} 4 \mathrm{Cl}, \mathrm{KCl}+$ methylamine and $\mathrm{KCl}+$ bafilomycin, respectively $(\mathbf{K})$. Note that the rate of $\mathrm{K}+-$ induced exocytosis and FM1-43 destaining was not affected by agents which collapse the electrochemical gradient and reduce the quantal content. Error bars: \pm SEM of 252 spots from 31 nerve terminals. Scale Bar for all images $=10 \mu \mathrm{m}$.

perfused with high $\mathrm{K}^{+}$solution, FM1-43 and $0 \mathrm{mM} \mathrm{Ca}^{2+}$ in the presence of methylamine (Figure $3 \mathrm{~A}$ ), $\mathrm{NH}_{4} \mathrm{Cl}$ (Figure 3C) and bafilomycin (Figure 3E), exhibit fluorescence only at the plasma membrane. When these terminals were perfused with the same solution but in the presence of $2.5 \mathrm{~mm} \mathrm{Ca}^{2+}$, the fluorescence was internalized during depolarization in the synaptic terminals for all the experimental conditions tested (Figure 3B, D, F).

FM1-43 loading represents endocytosis of SVs and the endocytic rate is highly related to the previous exocytosis (Wu et al., 1996). Thus, this enabled investigation of vesicle exo and endocytosis by observing the amount of FM1-43 loading in the bipolar cell synaptic terminals. As can be observed in Fig 3G, the quantification of FM1-43 fluorescence was the same for all substances tested.

Despite controversy about glutamate filling, it seems that $\Delta \Psi$ drives glutamate uptake but $\Delta \mathrm{pH}$ may avoid neurotransmitter efflux (Wolosker et al., 1996). Thus,
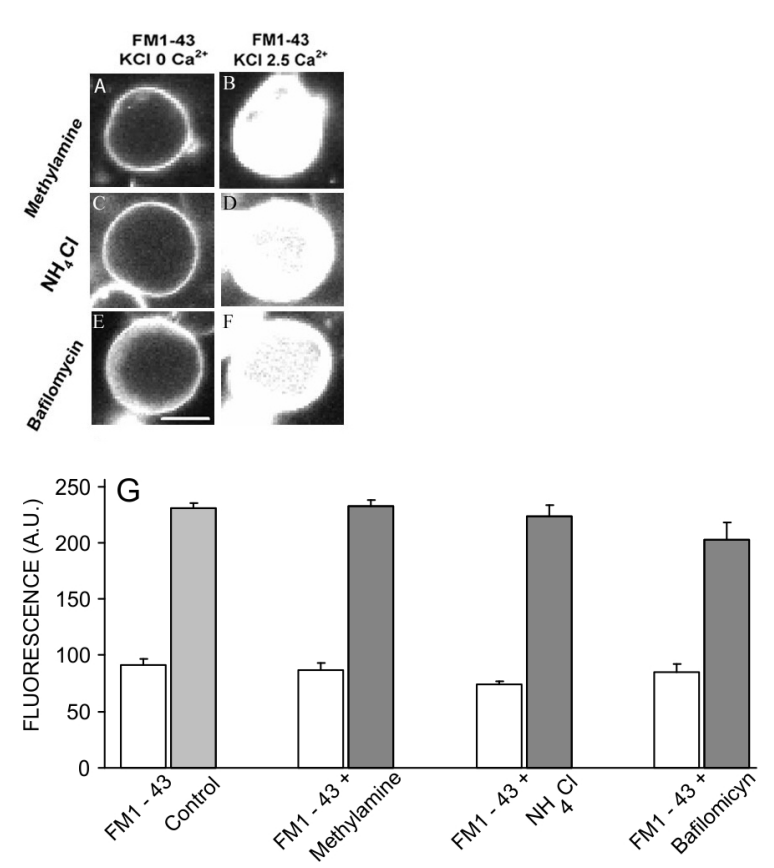

FIGURE 3 - Synaptic vesicle trafficking is not altered when vesicles exhibit deficits in acidification and filling at retinal bipolar cells. Bipolar cell terminals incubated with methylamine $10 \mathrm{~mm}(\mathbf{A}), \mathrm{NH}_{4} \mathrm{Cl} 30 \mathrm{~mm}(\mathbf{C})$ and bafilomycin $500 \mathrm{~nm}(\mathbf{E})$ for 5 min were perfused with fish Ringer containing $\mathrm{KCl} 50 \mathrm{~mm}+$ FM1-434 $\mu \mathrm{M}+\mathrm{Ca}^{2+} 0 \mathrm{~mm}$ for $2 \mathrm{~min}$. The same cells were then perfused with Fish Ringer containing $\mathrm{KCl} 50 \mathrm{~mm}+$ FM1-434 $\mu \mathrm{M}+\mathrm{Ca}^{2+} 2.5 \mathrm{~mm}$ for $6 \mathrm{~min}$ in the continued presence of methylamine (B), $\mathrm{NH}_{4} \mathrm{Cl}(\mathbf{D})$ and bafilomycin $(\mathbf{F})$. Quantification of FM1-43 staining after 6 min of stimulus with $\mathrm{KCl}(50 \mathrm{~mm}), \mathrm{KCl}(50 \mathrm{~mm})+\mathrm{NH}_{4} \mathrm{Cl}(30 \mathrm{~mm}), \mathrm{KCl}(50 \mathrm{~mm})+$ methylamine (10 mM) and $\mathrm{KCl}(50 \mathrm{~mm})+$ bafilomycin $(500 \mathrm{~nm})$ in the presence of FM1-43 (G). Control $\mathrm{n}=10$; methylamine $\mathrm{n}=9 ; \mathrm{NH}_{4} \mathrm{Cl} \mathrm{n}=9$; bafilomycin $\mathrm{n}=8$. Scale bar $5 \mu \mathrm{m}$.

SV filling was blocked in experiments with bafilomycin although methylamine and $\mathrm{NH}_{4} \mathrm{Cl}$ might also have caused filling alterations.

The $\mathrm{pH}$ levels inside secretory vesicles may modulate many aspects of synaptic function, such as vesicle matrix organization, transport activity of small molecules, activity and maturation of prohormones (Blackmore et al., 2001) and reacidification of SV after a round of exocytosis. Therefore, the $\mathrm{pH}$ levels inside vesicles could be a limiting factor during the entire synaptic cycle (Melnik et al., 2001).

On the other hand, an appropriate number of SV filled with a discrete amount of neurotransmitters is needed to sustain synaptic transmission during prolonged depolarization (Edwards, 2007).

In the present work, experiments were performed using the styryl dye FM1-43, a powerful tool for visualizing exocytosis and endocytosis in neuronal and non-neuronal 
cell types (Amaral et al., 2011). Using a very similar stimulus protocol for comparison, results showed that vesicle acidification and filling are not required for normal vesicle trafficking in two very distinct synapses: a cholinergic frog neuromuscular junction and a glutamatergic central ribbon type synapse in the retina. We looked for vesicle trafficking impairments when SVs of both synapses show acidification deficits acquired with membrane-permeable weak bases. Specifically in the case of the neuromuscular junction, $\Delta \mathrm{pH}$ collapse by $\mathrm{NH}_{4} \mathrm{Cl}$ and methylamine also leads to a decrease in SV filling. Furthermore, we studied whether $\Delta \mu \mathrm{H}+$ disruption produced by bafilomycin incubation could affect vesicle cycling.

Supporting these results, a body of evidence suggests that empty SV undergo exo/endocytosis when vesicle acidification and filling are impaired in other experimental models (Cousin, Nicholl, 1997; Parsons et al., 1999; Zhou et al., 2000).

In contrast to the neuromuscular junction, a conventional synapse that encodes information by changing the rate of action potentials (Fagerlund, Eriksson, 2009), bipolar cells transmit their signals tonically and in a graded fashion (tom Dieck, Brandstätter, 2006; Tachibana, 1999). To accomplish this, the compound fusion of SV assures high release rates during strong repetitive stimulation in ribbon synapses (Matthews, Sterling, 2008), even though other rat and mouse synapses also show this mechanism (He et al., 2009). Additionally, glutamate and acetylcholine are accumulated into vesicles using different energetic components of the proton motive force set up across the vesicle membrane by the $\mathrm{VH}^{+}$-ATPase. Due to these remarkable differences, it is reasonable to propose that mechanisms regulating $\mathrm{SV}$ cycling might differ between these synapses.

Interestingly, the number of recycling vesicles and the SV cycle remain preserved at the neuromuscular junctions of mice with decreased VAChT protein expression (VAChT knockdown), which in itself is sufficient to reduce quantal size and post-synaptic events (Prado et al., 2006). In fact, even in the complete absence of SV transporters for acetylcholine (de Castro et al., 2009), dopamine and glutamate in knock-out mice, FM1-43 staining and destaining remain unaltered (Croft et al., 2005). The authors hypothesize that a distinct pool of empty SVs would undergo exocytosis and endocytosis, incorporating the vesicular transporter depending on their local availability (Prado et al., 2006).

We cannot rule out the possibility that only a small amount of SV that underwent recycling was truly empty and not acidified and that some fully-filled and acidic vesicles could cycle in a prolonged high $\mathrm{K}+$ stimulus.
However, using electrophysiological techniques, Hong (2001) reported that bafilomycin A and Concanamycin A applied at mouse diaphragm neuromuscular junctions in concentrations and for a period of incubation equivalents to those used in our experiments resulted in twitch tension depression and reduction of quantal size, EPPs and MEEPs amplitude. Additionally, Zhou and colleagues (2000) also observed that incubation with bafilomycin A reduced the amplitude and frequency of miniature inhibitory postsynaptic currents (mIPSCs) in rat hippocampal slices. Furthermore, they also reported that similar results were seen in glutamatergic miniature excitatory postsynaptic currents (mEPSCs) and GABAergic mIPSCs from cultured neurons. Finally, our previous work demonstrated that bafilomycin, $\mathrm{NH}_{4} \mathrm{Cl}$ and methylamine (with the same concentrations and period of incubation used here) decreased SV acidification in the bipolar cell terminals in a rapid fashion (Abreu et al., 2008). In summary, our data with image techniques are in agreement with electrophysiological data, lending further support to the notion that the synaptic vesicle cycle is independent of vesicle filling or type of synapse.

Could the cycling of SVs with reduced or absent quantal content have any physiological relevance? The exo/endocytosis cycle permits fast molecular changes between the plasma membrane and endossome and SV membranes. This membrane flux could be important for the maintenance of plasma membrane lipid composition or for the trafficking of proteins that are mobilized from intracellular membranes when they are recruited for action on the presynaptic membrane. For example, since the high affinity acetylcholine transporter (CHT1) is predominantly present in SVs and its regulation is closely linked to the exocytotic release of acetylcholine, it has been proposed that SVs may play a role in delivering the choline transporter to the cell surface (Ribeiro et al., 2003; Ribeiro et al., 2006). Indeed, Ribeiro and colleagues (2007) demonstrated that CHT1 recycles back to the cell surface and that $\mathrm{K}^{+}$-induced depolarization increases $\mathrm{CHT} 1$ cell surface localization by enhancing the recruitment of intracellular transporters to the cell surface. The transport of these proteins, along the SV-cell membrane could explain how some neurons support neurotransmission signals during intense activity.

\section{ACKNOWLEDGMENTS}

The work was supported by grants from CNPq, FAPEMIG and CAPES, PRONEX. The authors thank Mirian Stella Maris for revising this manuscript. 


\section{REFERENCES}

ABREU, B.J.; GUIMARÃES, M.; ULIANA, L.C.; VIGH, J.; VON GERSDORFF, H.; PRADO, M.A.; GUATIMOSIM, C. Protein kinase $\mathrm{C}$ modulates synaptic vesicle acidification in a ribbon type nerve terminal in the retina. Neurochem. Int., v.53, p.155-164, 2008.

AMARAL, E.; GUATIMOSIM, S.; GUATIMOSIM, C. Using the fluorescent styryl dye FM1-43 to visualize synaptic vesicles exocytosis and endocytosis in motor nerve terminals. Methods Mol. Biol., v.689, p.137-148, 2011.

BETZ, W.J.; MAO, F.; BEWICK, G.S. Activity dependent fluorescent staining and destaining of living vertebrate motor nerve terminals. J. Neurosci., v.12, p.363-375, 1992.

BLACKMORE, C.G.; VARRO, A.; DIMALINE, R.; BISHOP, L.; GALLACHER, D.V.; DOCKRAY, G.J. Measurement of secretory vesicle $\mathrm{pH}$ reveals intravesicular alkalinization by vesicular monoamine transporter type 2 resulting in inhibition of prohormone cleavage. J. Physiol., v.531, p.605-617, 2001.

COUSIN, M.A.; NICHOLLS, D.G. Synaptic vesicle recycling in cultured cerebellar granule cells: role of vesicular acidification and refilling. J. Neurochem., v.69, p.19271935, 1997.

CROFT, B.G.; FORTIN, G.D.; CORERA, A.T.; EDWARDS, R.H.; BEAUDET, A.; TRUDEAU, L.E.; FON, E.A. Normal biogenesis and cycling of empty synaptic vesicles in dopamine neurons of vesicular monoamine transporter 2 knockout mice. Mol. Biol. Cell., v.16, p.306-315, 2005.

DANBOLT, N.C. Glutamate uptake. Prog. Neurobiol., v.1, p.1-105, 2001.

DE CASTRO, B.M.; DE JAEGER, X.; MARTINS-SILVA, C.; LIMA, R.D.; AMARAL, E.; MENEZES, C.; LIMA, P.; NEVES, C.M.; PIRES, R.G.; GOULD, T.W.; WELCH, I.; KUSHMERICK, C.; GUATIMOSIM, C.; IZQUIERDO, I.; CAMMAROTA, M.; RYLETT, R.J.; GOMEZ, M.V.; CARON, M.G.; OPPENHEIM, R.W.; PRADO, M.A.; PRADO, V.F. The vesicular acetylcholine transporter is required for neuromuscular development and function. Mol. Cell. Biol., v.29, p.5238-5250, 2009.

EDWARDS, R.H. The neurotransmitter cycle and quantal size. Neuron., v.55, p.835-858, 2007.
FAGERLUND, M.J.; ERIKSSON, L.I. Current concepts in neuromuscular transmission. Br. J. Anaesth., v.103, p.108114, 2009.

LAGNADO, L.; GOMIS, A.; JOB, C. Continuous vesicle cycling in the synaptic terminal of retinal bipolar cells. Neuron., v.17, p.957-967, 1996.

LIMA, R.F.; PRADO, V.F.; PRADO, M.A.; KUSCHMERICK, C. Quantal release of acetylcholine in mice with reduced levels of the vesicular acetylcholine transporter. $J$ Neurochem., v.113, p.943-951, 2010.

LIU, Y.; EDWARDS, R.H. The role of vesicular transport proteins in synaptic transmission and neural degeneration. Annu. Rev. Neurosci., v.20, p.125-156, 1997.

HARTINGER, J.; JAHN, R. An anion binding site that regulates the glutamate transporter of synaptic vesicles. J. Biol. Chem., v.268, p.23122-23127, 1993.

HE, L.; XUE, L.; XU, J.; MCNEIL, B.D.; BAI, L.; MELICOFF, E.; ADACHI, R.; WU, L.G. Compound vesicle fusion increases quantal size and potentiates synaptic transmission. Nature, v.459, p.93-97, 2009.

HONG, S.J. Reduction of quantal size and inhibition of neuromuscular transmission by bafilomycin A. Neuropharmacology, v.41, p.609-617, 2001.

MATTHEWS, G.; STERLING, P. Evidence that vesicles undergo compound fusion on the synaptic ribbon. $J$. Neurosci., v.28, p.5403-5411, 2008.

MAYCOX, P.R.; HELL, J.W.; JAHN, R. Amino acid neurotransmission: spotlight on synaptic vesicles. TINS., v.13, p.83-87, 1988.

MELINIK, V.I.; BIKBULATOVA, L.S.; GULYAEVA, N.V.; BAZYAN, A.S. Synaptic vesicle acidification and exocytosis studied with acridine orange fluorescence in rat brain synaptosomes. Neurochem. Res., v.26, p.549-554, 2001.

MORIYAMA, Y.; FUTAI, M. H(+)-ATPase, a primary pump for accumulation of neurotransmitters, is a major constituent of brain synaptic vesicles. Biochem. Biophys. Res. Commun., v.173, p.443-448, 1990.

NAITO, S.; UEDA, T. Characterization of glutamate uptake into synaptic vesicles. J. Neurochem., v.44, p.99-109, 1985. 
NELSON, N. Structural conservation and functional diversity of V-ATPases. J. Bioenerg. Biomembr., v.24, p.407-414, 1992.

PARSONS, R.L.; CALUPCA, M.A.; MERRIAN, L.A.; PRIOR, C. Empty synaptic vesicles recycle and undergo exocytosis at vesamicol-treated motor nerve terminals. $J$. Neurophysiol., v.81, p.2696-2700, 1999.

PRADO, V.F.; MARTINS-SILVA, C.; DE CASTRO, B.M.; LIMA, R.F.; BARROS, D.M.; AMARAL, E.; RAMSEY, A.J.; SOTNIKOVA, T.D.; RAMIREZ, M.R.; KIM, H.G.; ROSSATO, J.I.; KOENEN, J.; QUAN, H.; COTA, V.R.; MORAES, M.F.; GOMEZ, M.V.; GUATIMOSIM, C.; WETSEL, W.C.; KUSHMERICK, C.; PEREIRA, G.S.; GAINETDINOV, R.R.; IZQUIERDO, I.; CARON, M.G.; PRADO, M.A. Mice deficient for the vesicular acetylcholine transporter are myasthenic and have deficits in object and social recognition. Neuron., v.51, p.601-612, 2006.

RIBEIRO, F.M.; ALVES-SILVA, J.; VOLKNANDT, W.; MARTINS-SILVA, C.; MAHMUD, H.; WILHELM, A.; GOMEZ, M.V.; RYLETT, R.J.; FERGUSSON, S.S.; PRADO, V.F.; PRADO, M.A. The hemicholinium-3 sensitive high affinity choline transporter is internalized by clathrin-mediated endocytosis and is present in endosomes and synaptic vesicles. J. Neurochem., v.87, p.136-146, 2003.

RIBEIRO, F.M.; BLACK, S.A.; PRADO, V.F.; RYLETT, R.J.; FERGUSSON, S.S.; PRADO, M.A. The "ins" and "outs" of the high-affinity choline transporter CHT1. J. Neurochem., v.97, p.1-12, 2006.

RIBEIRO, F.M.; PINTHONG, M.; BLACK, S.A.; GORDON, A.C.; PRADO, V.F.; PRADO, M.A.; RYLETT, R.J.; FERGUSSON, S.S. Regulated recycling and plasma membrane recruitment of the high-affinity choline transporter. Eur. J. Neurosci., v.26, p.3437-3448, 2007.

SUDHOF, T.C. The synaptic vesicle cycle. Annu. Rev. Neurosci., v.27, p.509-547, 2004.

TABB, J.S.; KISH, P.E.; VAN DYKE, R.; UEDA, T. Glutamate transport into synaptic vesicles. Roles of membrane potential, $\mathrm{pH}$ gradient, and intravesicular pH. J. Biol. Chem., v.267, p.15412-15418, 1992.
TACHIBANA, M. Regulation of transmitter release from retinal bipolar cells. Prog. Biophys. Mol. Biol., v.72, p.109-133, 1999.

TOM DIECK, S.; BRANDSTATTER, J.H. Ribbon synapses of the retina. Cell Tissue Res., v.326, p.339-346, 2006.

VAN DER KLOOT, W. Inhibition of packing of acetylcholine into quanta by ammonium. FASEB J., v.1, p.298-302, 1987.

VAN DER KLOOT, W.; MOLGÓ, J.; CAMERON, R.; COLASANTE, C. Vesicle size and transmitter release at the frog neuromuscular junction when quantal acetylcholine content is increased or decreased. J. Physiol., v.541, p.385393, 2002.

VON GERSDORFF, H.; MATTHEWS, G. Dynamics of synaptic vesicle fusion and membrane retrieval in synaptic terminals. Nature, v.367, p.735-739, 1994.

WOLOSKER, H.; DE SOUZA, D.O.; DE MEIS, L. Regulation of glutamate transport into synaptic vesicles by chloride and proton gradient. J. Biol. Chem., v.271, p.11726-11731, 1996.

WU, L.G.; BETZ, W.J. Nerve activity but not intracellular calcium determines the time course of endocytosis at the frog neuromuscular junction. Neuron., v.17, p.769-779, 1996.

ZHOU, Q.; PETERSEN, C.C.; NICOLL, R.A.; Effects of reduced vesicular filling on synaptic transmission in rat hippocampal neurons. J. Physiol., v.25, p.195-206, 2000.

ZOCCARATO, F.; CAVALlini, L.; ALEXANDRE, A. The adenosine inhibition of glutamate exocytosis in synaptosomes is removed by the collapse of the vesiclecytosol $\triangle \mathrm{pH}$ plus the opening of farnesol-sensitive $\mathrm{Ca} 2+$ channels. Cell Calcium, v.33, p.273-282, 2003.

Received for publication on $14^{\text {th }}$ July 2011 Accepted for publication on $04^{\text {th }}$ January 2012 